\title{
Pengaruh GDP, Ekspor dan Investasi Terhadap Inflasi di Lima Negara Anggota IDB
}

\author{
Novita $^{1}$ and Sri Herianingrum ${ }^{2}$ \\ Magister of Islamic Economic, Faculty of Economic and Business, Airlangga University ${ }^{1}$ \\ Lecturer of Islamic Economic, Faculty of Economic and Business, Airlangga University ${ }^{2}$ \\ Email: novita-2018@pasca.unair.ac.id
}

\begin{abstract}
Penelitian ini bertujuan ingin mengetahui seberapa besar pengaruh GDP, ekspor dan investasi terhadap inflasi di lima negara anggota IDB yaitu, Guinea Malaysia, Indonesia, Brunei dan Jordan. Hasil yang diperoleh dengan menggunakan analisis kuantitatif regeresi data panel dihasilkan bahwa ada pengaruh GDP, ekspor dan investasi terhadap inflasi tetapi tidak signifikan terhadap kelima negara anggota IDB ini Banyak faktor outlier yang juga ikut mempengaruhi salah satunya karena mulai diterapkan perekonomian bebas bunga. Penelitian ini ingin mengamati faktor-faktor apa saja yang mempengaruhi inflasi dinegara Guinea yang merupakan salah satu negara anggota IDB yang memiliki karakteristik termiskin diantara negara-negara lainnya. Hasil yang diperoleh dengan menggunakan analisis kuantitatif metode regresi linier berganda data panel dan asumsi klasik dihasilkan bahwa ketiga variabel independen berpengaruh terhadap variabel dependen tetapi tidak signifikan. Dimana hubungan antara DGP dan inflasi positif, artinya bila GDP naik maka inflasi juga naik. Sedangkan hubungan antara ekspor dan investasi terhadap inflasi adalah negatif. Artinya bila ekspor naik maka inflasi turun dan jika investasi naik maka inflasi akan turun. Sehingga secara umum kebijakan pemerintah dari lima negara anggota IDB tersebut harus lebih berpihak kepada menaikkan tingkat ekspor dan investasi di dalam negeri baik investasi asing atau investasi domestik untuk membantu menurunkan tingkat inflasi dalam negeri.
\end{abstract}

Keywords: Inflasi, Data panel, IDB, GDP.

Abstract: The aims of this study is to find out how much influence GDP, exports and investment have on inflation in the five IDB member countries, namely Guinea, Malaysia, Indonesia, Brunei and Jordan. The results obtained by using a quantitative analysis of panel data re-sultations resulted that there was an influence of GDP, exports and investment on inflation but not significantly to these five IDB member countries. Many outlier factors also influenced one of them because the interest-free economy began to be implemented. This study wants to observe what factors influence inflation in the country of Guinea which is one of the IDB member countries that has the poorest characteristics among other countries. The results obtained using quantitative analysis methods of multiple linear regression panel data and classical assumptions produced that the three independent variables affect the dependent variable but not significant. Where the relationship between DGP and inflation is positive, meaning that if GDP rises, inflation also rises. While the relationship between exports and investment to inflation is negative. This means that if exports rise, inflation will decrease and if investment rises, inflation will fall. So in general the government policies of 
the five IDB member countries must be more pro-aligned to raise the level of exports and investment in the country both foreign investment and domestic investment to help reduce the level of domestic inflation.

Keywords: inflation, panel data, GNI, GDP.

\section{PENDAHULUAN}

Penelitian ini bertujuan untuk mengamati faktor-faktor yang bisa mempengaruhi inflasi dinegara Guinea yang merupakan salah satu negara anggota IDB yang memiliki karakteristik termiskin diantara negara-negara lainnya. Hasil dari pengamatan ini akan menjadi bahan pelajaran yang penting bagi negara-negara lain berkaca dari kondisi nyata dari Guinea. Bagaimana negara dengan kondisi termiskin dalam keanggotaan IDB dapat tetap survive hingga sekarang. Selain negara Guinea penelitian ini juga mengamati faktorfaktor yang mempengaruhi inflasi di negara Indonesia, Malaysia, Brunei dan negara Jordan sebagai pembanding. Alasan dipilihnya negara Indonesia yang merupakan negara muslim terbesar di dunia sedangkan negara Jordan termasuk sepuluh negara terkaya didunia. Adapun negara Malaysia dan negara Brunei merupakan negara yang dekat dengan negara Indonesia dikawasan asia tenggara.

Bila dibandingkan dengan penelitian sebelumnya yang sejenis dikatahui bahwa perubahan ekonomi akan mempengaruhi pada pengeluaran yang lebih tinggi diberbagai tingkatan baik ditingkat rumahtangga ataupun negara sehingga perlu adanya langkahlangkah bijak (Ikasari, 2015). Sehingga rumusan masalahyang timbul dari penelitian ini adalah faktor apa saja yang bisa mempengaruhi inflasi dinegara Guinea, negara Indonesia, negara Malaysia, negara Brunei dan negara Jordan? Seberapa besar pengaruh nya? Serta analisis nya dengan menggunakan analisis regresi data panel. Variabel independen nya yang diamati sebagai model adalah GDP, ekspor dan inflasi. Inflasi merupakan masalah ekonomi yang terus menerus diamati dan sangat menarik. Selalu dicari solusi terbaiknya dari waktu kewaktu. Efek dari adanya inflasi dalam suatu negara tidak hanya mendongkrak kenaikan harga-harga barang dan jasa serta menurunkan nilai tukar mata uang negara tersebut tetapi juga menghilangkan kepercayaan masyarakat terhadap pemerintahannya.

Kehilangan kepercayaan dari masyarakat adalah hal terburuk dalam proses berjalannya roda suatu pemerintahan. Inflasi sering didefinisikan sebagai kecenderungan dari adanya peningkatan harga secara terus menerus. Menurut wikipedia didefinisikan sebagai "Inflation is a rise in the general level of prices of goods and services in an economic over a period of time”. Menurut salah satu ahli ekonomi Frank Shostak, inflasi merupakan salah satu faktor dominan yang banyak menyebabkan kerusakan dalam ekonomi, bukan hanya sekedar masalah kenaikan harga. Sedangkan inflasi menurut IMF adalah hasil dari agregat demand melebihi agregat supply.

Para ahli ekonomi sependapat bahwa ada beberapa masalah jangka pendek ekonomi makro yang utama adalah inflasi, pengangguran dan neraca pembayaran. Indikator stabilitas ekonomi sangatlah banyak akan tetapi inflasi sering kali dijadikan salah satu indikator stabilitas perekonomian yang sangat mudah sehingga laju perubahannya selalu diupayakan berada pada tingkat yang rendah dan stabil.Tujuan utama dari penerapan berbagai kebijakan ekonomi adalah menciptakan kesejahteraan untuk seluruh rakyat tanpa terkecuali atau 
pemerataan distribusi pendapatan di semua lapisan masyarakat dalam suatu negara. Hal ini sesuai dengan prinsip dalam Islam dalam al Quran surat al Hasyr ayat 7.

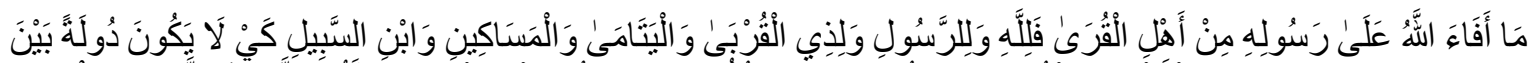

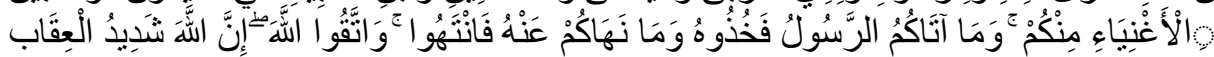

"Apasaja harta rampasan yang diberikan Allah kepada Rasul Nya (dari harta benda) yang berasal dari penduduk kota-kota maka adalah untuk Allah, untuk rasul, kaum kerabat, anak-anak yatim, orang-orang miskin dan orang-orang yang dalam perjalanan, supaya harta itu jangan beredar diantara orang orang kaya saja diantara kamu. Apa yang diberikan rasul kepadamu, maka terimalah dan apa yang dilarangnya bagimu, maka tinggalkanlah.dan bertaqwalah kepada Allah. Sesungguhnya Allah amat keras hukumannya."

Inflasi sangat mempengaruhi perubahan pendapatan masyarakat, perubahannya dapat bersifat menguntungkan atau merugikan bagi negara tersebut. Pada beberapa kondisi inflasi dapat mendorong perkembangan ekonomi dalam negeri suatu negara. Dikarenakan inflasi dapat mendorong para pengusaha dan produsen memperluas produksinya, sehingga akan tumbuh kesempatan lapangan kerja baru sekaligus dapat menyebabkan bertambahnya pendapatan seseorang atau sekelompok orang. Namun bagi masyarakat yang memiliki tingkat penghasilan tetap inflasi akan menyebabkan mereka rugi dikarenakan jumlah penghasilan yang tetap itu jika ditukarkan dengan barang dan jasa akan semakin sedikit disebabkan oleh inflasi. Selain bisa merusak tatanan ekonomi didalam suatu negara inflasi juga sangat dapat mempengaruhi perdagangan internasional antar negara. Bila tingkat inflasi dalam negeri terlalu tinggi maka akan menyebabkan turunnya daya saing barang dan jasa dalam negeri terhadap barang dan jasa dari luar negeri. Bahkan dalam kondisi yang serius, harga barang dan jasa dalam negeri bisa lebih tinggi dibandingkan harga barang dan jasa produksi luar negeri. Akibatnya aktivitas impor akan meningkat untuk memenuhi kebutuhan barang dan jasa dalam negeri. Negara yang sehat seharusnya tingkat ekspor yang tinggi bukan tingkat import yang naik. Untuk itu inflasi harus dapat segera diatasi, karena inflasi yang buruk akan mengurangi investasi diikuti dengan berkurangnya kegiatan ekonomi dan bertambahnya pengangguran disebabkan tingkat produksi yang menurun sehingga memperlambat pertumbuhan ekonomi negara.

Produk Domestik Bruto atau GDP merupakan pengukuran yang paling luas dari total barang dan jasa yang dihasilkan oleh suatu negara dengan menggunakan faktor-faktor produksi yang dimiliki oleh penduduk negara tersebut atau perusahaan negara lain. Produk domestik bruto merupakan penjumlahan dari beberapa faktor didalamnya seperti nilai konsumsi (C), investasi bruto (I), pembelanjaan pemerintah atas barang dan jasa (G) dan ekspor netto $(\mathrm{X})$ yang dihasilkan dalam suatu negara dalam masa satu tahun tertentu.

Tingkat pengembalian investasi riil bagi pengusaha dan pemodal adalah tidak dipengaruhi oleh inflasi dalam ekonomi bebas bunga. Sebab tingkat pengembalian investasi riil bagi penabung dilindungi selama masa inflasi, inflasi juga tidak mempengaruhi keputusannya untuk mengendalikan aset finansial. Oleh karena itu keuangan sangat berhubungan dengan inflasi, terantisipasi dan tidak terantisipasi, dalam sistem ekonomi berdasarkan bunga, dan demikian itu tidak akan berlaku dalam ekonomi bebas bunga. Oleh karena itu, bagi negara-negara yang berkeinginan bebas dari persoalan inflasi maka 
berpindah dari sistem keuangan berdasarkan bunga ke sistem keuangan bebas bunga merupakan sebuah keniscayaan. (Majid, 2003).

\section{KAJIAN TEORI}

Ekspor. (Agustina dan Reny, 2014); (Benny, 2013) Kegiatani perdagangan internasional yang memberikan rangsangan guna membutuhkan permintaan dalam inegeri yang menyebabkani tumbuhnya negara pabrik besar, bersamaani idengan struktur politik yang stabil dan lembaga yang fleksibel. Berdasarkan uraian idi atas, terlihat bahwa ekspor mencerminkan aktivitas perdagangan antarbangsa yang dapat memberikan dorongan dalam dinamika pertumbuhan perdagangan internasional, sehingga suatu negara yang sedang berkembang kemungkinan untuk mencapai kemajuan perekonomian setaraf dengan negara yang lebih maju (Todaro, 2002).

Dalam perdagangan internasional ekspor merupakan kegiatan sangat penting, sebagai transaksi kepada negara lain dengan menggunakan pembayaran, sesuai dengan kualitas,kuantitas dan syarat penjualan lain yang disetujui ekspor dan importir. Setiap harus berupaya mengahasilakan barang dan jasa yang mampu bersaing di pasar internasional (Sonia dan Setiawina, 2016). Berdasarkan uraian di atas, terlihat bahwa ekspor mencerminkan aktivitas perdagangan antar bangsa yang dapat memberikan dorongan dalam dinamika pertumbuhan perdagangan internasional, sehingga suatu negara yang sedang berkembang kemungkinan untuk mencapai kemajuan perekonomian setaraf dengan negara yang lebih maju.

Teori Investasi. Menurut (Fahmi, 2014) pengaruh anggaran pemerintah (government budget) terhadap pertumbuhan ekonomi adalah dapat memperbesar anggaran pengeluaran dalam perekonomian mengalami kelesuan sehingga lapangan pekerjaan meningkat dan akhirnya akan meningkatkan pendapatan masyarakat. Perubahan yang terjadi akibat pengeluaran pemerintah akan berpengaruh pada peningkatan pendapatan nasional, disebut sebagai proses multiplier. Untuk mencapai suatu efektifitas dan efisiensi dalam keputusan investasi kita perlu menetapkan tujuan yang hendak dicapai yaitu: (1) Terciptanya continuity dalam investasi. (2) Terciptanya profit yang maksimum. (3) Terciptanya kemakmuran pemegang saham. (4) Memberikan andil bagi pembangunan bangsa.

IDB. Islamic Development Bank atau yang biasa disingkat IDB, merupakan lembaga keuangan internasional yang dilahirkan oleh negara-negara yang tergabung dalam Organisasi Konferensi Islam (OKI) pada tanggal 20 Oktober 1975 (15 Syawal 1395 H), yang berkantor pusat di Jeddah, Arab Saudi. IDB juga memiliki kantor regionalnya di beberapa negara seperti di Rabat, Maroko (1994); Kuala Lumpur, Malaysia (1994); Almaty, Kazakhstan (1997); dan Dakar, Senegal (2008). IDB juga memiliki perwakilan di 12 negara yaitu Afghanistan, Azerbaijan, Bangladesh, Guinea Conakry, Indonesia, Iran, Nigeria, Pakistan, Sierra Leone, Sudan, Uzbekistan dan Yaman. Bahasa resmi dalam kesehariannya yang digunakan adalah bahasa Arab, namun bahasa Inggris dan Perancis juga digunakan. Tahun yang dipakai dalam keseharian IDB adalah tahun Hijriah dalam Financial Yearnya.

Fungsi utama dari IDB adalah memberikan pinjaman untuk proyek-proyek produktif dalam pembangunan ekonomi dan sosial. Selain itu, IDB juga mendirikan dan mengoperasikan dana khusus untuk tujuan tertentu seperti dana bantuan untuk masyarakat 
Muslim di negara-negara non-anggota IDB dan berwenang untuk menerima dana dan memobilisasi dana tersebut berdasarkan sumber daya keuangan syariah yang kompatibel. Hal ini juga dituntut dengan tanggung jawab untuk membantu dalam promosi perdagangan luar negeri terutama dalam barang-barang modal di antara negara anggota yakni memberikan bantuan teknis kepada negara-negara anggota, dan memperluas fasilitas pelatihan untuk personil yang terlibat dalam kegiatan pembangunan di negara-negara Muslim untuk menyesuaikan diri dengan Syariah.

Adapun tujuan dari IDB sendiri adalah untuk mendorong pembangunan ekonomi dan kemajuan sosial negara-negara anggota dan masyarakat muslim baik secara perorangan maupun bersama-sama sesuai dengan prinsip-prinsip syariah yaitu, Hukum Islam. Demi mencapai tujuannya IDB memiliki visi untuk menjadi leader dalam mendorong pembangunan sosial ekonomi di negara-negara anggota dan masyarakat Muslim di negaranegara yang bukan negara anggota sesuai dengan prinsip syariah.

Inflasi. Bank Indonesia mendefinisikan inflasi adalah meningkatnya harga-harga secara umum dan terus menerus. Menurut Mishkin inflasi adalah kenaikan tingkat harga yang terjadi terus menerus, mempengaruhi individu, pengusaha, dan pemerintah. (Mishkin, 2008). Dalam teori kuantitas faktor utama yang menyebabkan inflasi adalah permintaan uang yang berlebihan sehingga masyarakat banyak memegang uang. Bertambahnya permintaan melebihi Gross National Product (GNP), akan terjadi inflationary gap yang kemudian menjadikan timbulnya inflasi. Kemudian pada Cost Push Inflation Apabila hargaharga faktor produksi semakin tinggi, yang menyebabkan semakin turunnya penawaran total, maka akan terjadi inflasi yang disertai resesi (Nurfadhilla, 2019).

Beberapa literature menjelaskan bahwa inflasi didefinisikan sebagai kenaikan harga umum secara terus menerus dari suatu perekonomian. Pengaruh inflasi terhadap NPF yaitu jika inflasi tinggi maka dapat menyebabkan menurunnya pendapatan riil masyarakat yang juga standar hidup masyarakat menurun. Sebelum terjadinya inflasi biasanya seorang debitur masih sanggup untuk membayar angsuran pembiayaannya. Namun, ketika terjadi inflasi harga-harga barang akan mengalami peningkatan yang cukup tinggi dari sebelumnya, sehingga masyarakat sulit untuk membayar pembiayaannya dikarenakan penghasilan yang didapatkan habis akan memenuhi kebutuhan sehari-harinya. (Setyawati, 2017).

Pertumbuhan Ekonomi. Pertumbuhan ekonomi adalah indikator makroekonomi yang menunjukan tingkat kesejahteraan masyarakat suatu negara. Seperti Inonesia sebagai negara yang berkembang, pertumbuhan ekonomi selalu menjadi pusat. Pertumbuhan ekonomi adalah penambahan PDB yang berarti juga pendapatan nasional. (Tulus, 2008). Pertumbuhan ekonomi dalam islam adalah pertumbuhan produksi barang dan jasa yang terus meningkat dengan menggunakan cara yang benar yang dapat memberikan kontribusi terhadap kesejahteraan masyrakat secara merata. Dalam pertumbuhan konvensional menggunakan GNP sebagai alat ukur dalam waktu tertentu sedangkan dalam pertumbuhan ekonomi Islam GNP ditambah dengan indikator zakat. (Tulus, 2008).

\section{METODOLOGI}

Penelitian ini menggunakan data yang dikelompokkan menjadi dua variabel yaitu variabel dependen dan variabel independen. Variabel independen adalah variabel yang 
bersifat menentukan atau mempengaruhi variabel dependen. Sedangkan variabel dependen adalah variabel yang dipengaruhi oleh variabel independen.

Variabel dependen. Variabel dependen yang digunakan dalam penelitian ini adalah inflasi di lima negara anggota IDB yaitu Guinea, Indonesia, Malaysia, Brunei dan Jordan periode tahun 2000 hingga 2015.

Variabel independen yang digunakan adalah GDP, ekspor dan investasi. Penelitian ini menggunakan metode regresi linier berganda data panel dan asumsi klasik untuk melihat bagaimana pengaruh GDP, ekspor dan investasi terhadap inflasi di lima negara anggota IDB yaitu Guinea, Malaysia, Indonesia, Brunei dan Jordan. Regresi linier adalah metode statistika yang digunakan untuk membentuk model hubungan antara variabel terikat (dependen, respon, Y) yaitu inflasi dan dengan satu atau lebih variabel bebas (independen, prediktor, X). Penelitian ini menggunakan data panel regresi linier berganda karena terdapat lebih dari satu variabel bebas yaitu sebanyak tiga variabel bebas diantaranya GDP,eksport dan investasi dalam lima negara yang diamati. Data untuk variabel independen X pada penelitian ini merupakan data yang telah ditetapkan (dikontrol) sebelumnya. Sehingga diharapkan informasi dari data sekunder yang digunakan lebih kuat dalam menjelaskan hubungan sebab akibat antara variabel $\mathrm{X}$ dan variabel $\mathrm{Y}$. Data sekunder yang digunakan dalam penelitian ini diambil dari https://isdbdata.github.io/monograph2017.htm. dan https://isdbdata.github.io/mc/IDN dan https://isdbdata.github.io/mc/gov_revenue Dari periode tahun 2000 hingga 2015. Program pengolahan data yang digunakan adalah data program E-views 9.

Data untuk variabel independen X pada penelitian ini merupakan data yang telah ditetapkan (dikontrol) sebelumnya. Sehingga diharapkan informasi dari data sekunder yang digunakan lebih kuat dalam menjelaskan hubungan sebab akibat antara variabel $\mathrm{X}$ dan variabel Y. Data sekunder yang digunakan dalam penelitian ini diambil dari https://isdbdata.github.io/monograph2017.htm. dan https://isdbdata.github.io/mc/IDN dan https://isdbdata.github.io/mc/gov revenue Dari periode tahun 2000 hingga 2015.

Program pengolahan data yang digunakan adalah data program E-views. Model persamaan dalam penelitian ini dapat dirumuskan sebagai:

$$
\mathrm{Y}=\alpha+\beta 1 \mathrm{X} 1+\beta 2 \mathrm{X} 2+\beta 3 \mathrm{X} 3+\varepsilon
$$

Dimana,

$\underline{Y=\text { inflasi }}$

$\mathrm{X} 1=\mathrm{GDP}$

$\underline{X 2=\text { Ekspor }}$

$\underline{\mathrm{X} 3=\text { Investasi }}$

$\alpha=$ Intercept

$\beta=$ Koefisien

$\varepsilon=$ Error Term

Uji Ordinary Least Square (OLS). Untuk melihat seberapa besar pengaruh GDP, GNI, jumlah uang beredar, ekspor dan jumlah hutang luar negeri terhadap inflasi di Republik 
Guinea dengan menggunakan uji Ordinary Least Square (OLS) dengan mengunakan program E-views 9.

Uji Heteroskedastisitas. Heterokedastisitas merupakan salah satu asumsi OLS jika varian residualnya tidak sama. Pengujian heterokedastisitas menggunakan uji white heterokedasticity, yang harus diperhatikan Obs*R-Square dan juga nilai probabilitynya. Apabila lebih rendah dari 0,05 berarti terdapat heterokedastisitas pada hasil estimasi dan begitu pula sebaliknya.

Multikolinearitas. Menggambarkan hubungan satu sama lain variabelnya.

\section{HASIL DAN ANALISIS}

\section{Tabel 1. Hasil Uji CEM}

\begin{tabular}{|c|c|c|c|c|}
\hline $\begin{array}{l}\text { Dependent Variable } \\
\text { Method: Panel Least } \\
\text { Date: } 10 / 11 / 19 \text { Tim } \\
\text { Sample: } 20002015 \\
\text { Periods included: } 16 \\
\text { Cross-sections inclu } \\
\text { Total panel (unbalan }\end{array}$ & $\begin{array}{l}\text { ares } \\
58 \\
5 \\
\text { observation }\end{array}$ & $: 77$ & & \\
\hline Variable & Coefficient & Std. Error & t-Statistic & Prob. \\
\hline C & 5.647725 & 1.429420 & 3.951061 & 0.0002 \\
\hline$\times 1$ & 0.289061 & 0.336637 & 0.858672 & 0.3933 \\
\hline$\times 2$ & $-2.38 E-05$ & 1.57E-05 & -1.514484 & 0.1342 \\
\hline$\times 3$ & 0.000129 & 0.000247 & 0.522543 & 0.6029 \\
\hline R-squared & 0.043307 & Mean depen & ent var & 5.568831 \\
\hline Adjusted R-squared & 0.003991 & S.D. depend & ht var & 6.947307 \\
\hline S.E. of regression & 6.933431 & Akaike info c & erion & 6.761137 \\
\hline Sum squared resid & 3509.290 & Schwarzcrit & ion & 6.882893 \\
\hline Log likelihood & -256.3038 & Hannan-Qui & criter. & 6.809838 \\
\hline F-statistic & 1.101500 & Durbin-Wats & n stat & 0.467923 \\
\hline Prob(F-statistic) & 0.354122 & & & \\
\hline
\end{tabular}

Sumber: (Data Diolah, 2019)

Hasil dari uji CEM dengan menggunakan data 5 negara selama 16 tahun dari tahun 2000 hingga 2015. Nilai R-squarenya lebih kecil daripada 0,5 berarti faktor ekspor, GDP dan investasi tidak signifikan mempengaruhi inflasi di lima negara anggota IDB yaitu negara Guinea, Indonesia, Malaysia, Brunei dan Jordan. GDP dan investasi berpengaruh positif terhadap inflasi artinya bila GDP dan investasi naik maka inflasi juga naik. Tetapi berbeda terhadap ekspor yang berpengaruh negatif terhadap inflasi, bila ekspor naik maka inflasi turun. 
Tabel 2. Hasil Uji FEM

\begin{tabular}{|c|c|c|c|c|}
\hline \multicolumn{5}{|c|}{$\begin{array}{l}\text { Dependent Variable: Y } \\
\text { Method: Panel Least Squares } \\
\text { Date: 10/11/19 Time: } 14: 01 \\
\text { Sample: } 20002015 \\
\text { Periods included: } 16 \\
\text { Cross-sections included: } 5 \\
\text { Total panel (unbalanced) observations: } 77\end{array}$} \\
\hline Variable & Coefficient & Std. Error & t-Statistic & Prob. \\
\hline $\begin{array}{l}c \\
\times 1 \\
\times 2 \\
\times 3 \\
\end{array}$ & $\begin{array}{r}5.171244 \\
0.183985 \\
-1.21 E-06 \\
-6.16 E-05 \\
\end{array}$ & $\begin{array}{l}2.085606 \\
0.300998 \\
3.34 E-05 \\
0.000281 \\
\end{array}$ & $\begin{array}{r}2.479492 \\
0.611252 \\
-0.036367 \\
-0.219234\end{array}$ & $\begin{array}{l}0.0156 \\
0.5430 \\
0.9711 \\
0.8271 \\
\end{array}$ \\
\hline \multicolumn{5}{|c|}{ Effects Specification } \\
\hline \multicolumn{5}{|c|}{ Cross-section fixed (dummyvariables) } \\
\hline $\begin{array}{l}\text { R-squared } \\
\text { Adjusted R-squared } \\
\text { S.E. of regression } \\
\text { Sum squared resid } \\
\text { Loglikelihood } \\
\text { F-statistic } \\
\text { Prob(F-statistic) }\end{array}$ & $\begin{array}{r}0.544705 \\
0.498515 \\
4.919775 \\
1670.089 \\
-227.7161 \\
11.79286 \\
0.000000\end{array}$ & \multicolumn{2}{|c|}{$\begin{array}{l}\text { Mean dependent var } \\
\text { S.D. dependent var } \\
\text { Akaike infocriterion } \\
\text { Schwarzcriterion } \\
\text { Hannan-Quinn criter. } \\
\text { Durbin-Watson stat }\end{array}$} & $\begin{array}{l}5.568831 \\
6.947307 \\
6.122496 \\
6.366008 \\
6.219899 \\
0.993493\end{array}$ \\
\hline
\end{tabular}

Sumber: (Data diolah, 2019)

Cara membaca hasil uji FEM sama dengan hasil uji CEM, yang membedakan adalah nilainya saja dan bentuk persamaan regresi data panelnya untuk uji FEM berdasarkan koefisien beta.

Setelah dilakukan uji CEM dan uji FEM dapat dilanjutkan dengan uji Chow. Karena dari hasil uji CEM dan uji FEM diketahui nilai probabilitasnya sehingga dapat dipilih Ho ataukah $\mathrm{H} 1$ nya.

\section{UJI CHOW}

$\mathbf{H}_{\mathbf{O}} \quad$ : Model CEM yang dipilih (Prob $\left.>0,05\right)$

H1 : Model FEM yang dipilih (Prob $<0,05)$ 
Tabel 3. Hasil Uji Chow

\begin{tabular}{|c|c|c|c|c|}
\hline \multicolumn{5}{|c|}{$\begin{array}{l}\text { Redundant Fixed Effects Tests } \\
\text { Equation: Untitled } \\
\text { Test cross-section fixed effects }\end{array}$} \\
\hline \multicolumn{2}{|l|}{ Effects Test } & Statistic & d.f. & Prob. \\
\hline \multicolumn{2}{|c|}{$\begin{array}{l}\text { Cross-section F } \\
\text { Cross-section Chi-square }\end{array}$} & $\begin{array}{l}18.996719 \\
57.175328 \\
\end{array}$ & $\begin{array}{r}(4,69) \\
4 \\
\end{array}$ & $\begin{array}{l}0.0000 \\
0.0000 \\
\end{array}$ \\
\hline \multicolumn{5}{|c|}{$\begin{array}{l}\text { Cross-section fixed effects test equation: } \\
\text { Dependent Variable: Y } \\
\text { Method: Panel Least Squares } \\
\text { Date: } 10 / 11 / 19 \text { Time: } 14: 02 \\
\text { Sample: } 20002015 \\
\text { Periods included: } 16 \\
\text { Cross-sections included: } 5 \\
\text { Total panel (unbalanced) observations: } 77\end{array}$} \\
\hline Variable & Coefficient & Std. Error & t-Statistic & Prob. \\
\hline $\begin{array}{l}\mathrm{C} \\
\times 1 \\
\times 2 \\
\times 3 \\
\end{array}$ & $\begin{array}{r}5.647725 \\
0.289061 \\
-2.38 E-05 \\
0.000129 \\
\end{array}$ & $\begin{array}{l}1.429420 \\
0.336637 \\
1.57 E-05 \\
0.000247 \\
\end{array}$ & $\begin{array}{r}3.951061 \\
0.858672 \\
-1.514484 \\
0.522543 \\
\end{array}$ & $\begin{array}{l}0.0002 \\
0.3933 \\
0.1342 \\
0.6029 \\
\end{array}$ \\
\hline $\begin{array}{l}\text { R-squared } \\
\text { Adjusted R-squared } \\
\text { S.E. of regression } \\
\text { Sum squared resid } \\
\text { Log likelihood } \\
\text { F-statistic } \\
\text { Prob(F-statistic) }\end{array}$ & $\begin{array}{r}0.043307 \\
0.003991 \\
6.933431 \\
3509.290 \\
-256.3038 \\
1.101500 \\
0.354122\end{array}$ & $\begin{array}{l}\text { Mean depen } \\
\text { S.D. depend } \\
\text { Akaike info c } \\
\text { Schwarzcrit } \\
\text { Hannan-Qui } \\
\text { Durbin-Wats }\end{array}$ & $\begin{array}{l}\text { entvar } \\
\text { ntvar } \\
\text { terion } \\
\text { ion } \\
\text { criter. } \\
\text { n stat }\end{array}$ & $\begin{array}{l}5.568831 \\
6.947307 \\
6.761137 \\
6.882893 \\
6.809838 \\
0.467923\end{array}$ \\
\hline
\end{tabular}

Sumber: (Data Diolah, 2019)

Berdasarkan hasil uji Chow seperti pada tabel 3 didapatkan bahwa model FEM yang lebih sesuai untuk data dalam penelitian ini, karena H1: Model FEM yang dipilih (Prob < 0,05) dan Ho ditolak maka model FEM yang lebih sesuai dengan data yang ada maka dibandingkan model FEM dengan model REM dengan menggunakan uji Hausman. 
Tabel 4. Hasil Uji REM

\section{UJI HAUSMAN}

$\mathbf{H}_{\mathbf{0}}$ : Model REM yang dipilih (Prob $>0,005$ )

$\mathbf{H}_{1}$ : Model FEM yang dipilih (Prob $\left.<0,005\right)$

\begin{tabular}{|c|c|c|c|c|}
\hline \multicolumn{5}{|c|}{$\begin{array}{l}\text { Dependent Variable: Y } \\
\text { Method: Panel EGLS (Cross-section random effects) } \\
\text { Date: } 10 / 11119 \text { Time: } 14: 03 \\
\text { Sample: } 20002015 \\
\text { Periods included: } 16 \\
\text { Cross-sections included: } 5 \\
\text { Total panel (unbalanced) observations: } 77 \\
\text { Swamyand Arora estimator of component variances }\end{array}$} \\
\hline Variable & Coefficient & Std. Error & t-Statistic & Prob. \\
\hline $\begin{array}{l}0 \\
\times 1 \\
\times 2 \\
\times 3\end{array}$ & $\begin{array}{r}5.485627 \\
0.179455 \\
-4.08 E-06 \\
-4.21 E-05\end{array}$ & $\begin{array}{c}5.293723 \\
0.298325 \\
3.12 E-05 \\
0.000270\end{array}$ & $\begin{array}{r}1.036251 \\
0.601543 \\
-0.130565 \\
-0.156109\end{array}$ & $\begin{array}{l}0.3035 \\
0.5493 \\
0.8965 \\
0.8764\end{array}$ \\
\hline \multicolumn{5}{|c|}{ Effects Specification } \\
\hline \multicolumn{5}{|c|}{ Weighted Statistics } \\
\hline $\begin{array}{l}\text { R-squared } \\
\text { Adjusted R-squared } \\
\text { S.E. of regression } \\
\text { F-statistic } \\
\text { Prob(F-statistic) }\end{array}$ & $\begin{array}{r}0.008225 \\
-0.032533 \\
4.820470 \\
0.201793 \\
0.894831 \\
\end{array}$ & \multicolumn{2}{|c|}{$\begin{array}{l}\text { Mean dependent var } \\
\text { S.D. dependent var } \\
\text { Sum squared resid } \\
\text { Durbin-Watson stat }\end{array}$} & $\begin{array}{l}0.638251 \\
4.745306 \\
1696.296 \\
0.978001\end{array}$ \\
\hline \multicolumn{5}{|c|}{ Unweighted Statistics } \\
\hline $\begin{array}{l}\text { R-squared } \\
\text { Sum squared resid }\end{array}$ & $\begin{array}{l}0.019959 \\
3594.934\end{array}$ & $\begin{array}{l}\text { Mean depen } \\
\text { Durbin-Wats }\end{array}$ & $\begin{array}{l}\text { ent var } \\
\text { C stat }\end{array}$ & $\begin{array}{l}5.568831 \\
0.461477\end{array}$ \\
\hline
\end{tabular}

Sumber: (Data Diolah, 2019) 
Tabel 5. Hasil Uji Hausman

Correlated Random Effects - Hausm an Test

Equation: Untitled

Test cross-section random effects

\begin{tabular}{lrrr}
\hline \hline Test Sum mary & Chi-Sq. Statistic & Chi-Sq.d.f. & Prob. \\
\hline \hline Cross-section random & 0.082755 & 3 & 0.9938 \\
\hline \hline
\end{tabular}

Cross-section random effects test comparisons:

\begin{tabular}{crrrr} 
Variable & Fixed & Random & Var(Diff.) & Prob. \\
\hline \hline X1 & 0.183985 & 0.179455 & 0.001602 & 0.9099 \\
X2 & -0.000001 & -0.000004 & 0.000000 & 0.8089 \\
X3 & -0.000062 & -0.000042 & 0.000000 & 0.8054 \\
\hline \hline
\end{tabular}

\begin{tabular}{|c|c|c|c|c|}
\hline \multicolumn{5}{|c|}{$\begin{array}{l}\text { Cross-section random effects test equation: } \\
\text { Dependent Variable: } Y \\
\text { Method: Panel Least Squares } \\
\text { Date: } 10 / 11 / 19 \text { Tim e: } 14: 04 \\
\text { Sample: } 20002015 \\
\text { Periods included: } 16 \\
\text { Cros s-sections included: } 5 \\
\text { Total panel (unbalanced) observations: } 77 \\
\end{array}$} \\
\hline Variable & Coefficient & Std. Error & t-Statistic & Prob. \\
\hline $\begin{array}{l}\mathrm{C} \\
\times 1 \\
\times 2 \\
\times 3 \\
\end{array}$ & $\begin{array}{r}5.171244 \\
0.183985 \\
-1.21 E-06 \\
-6.16 E-05 \\
\end{array}$ & $\begin{array}{r}2.085606 \\
0.300998 \\
3.34 \mathrm{E}-05 \\
0.000281 \\
\end{array}$ & $\begin{array}{r}2.479492 \\
0.611252 \\
-0.036367 \\
-0.219234 \\
\end{array}$ & $\begin{array}{l}0.0156 \\
0.5430 \\
0.9711 \\
0.8271 \\
\end{array}$ \\
\hline \multicolumn{5}{|c|}{ Effects Specification } \\
\hline \multicolumn{5}{|c|}{ Cross-section fixed (dum myvariables) } \\
\hline $\begin{array}{l}\text { R-squared } \\
\text { Adjusted R-s quared } \\
\text { S.E. of regression } \\
\text { Sum squared resid } \\
\text { Loglikelihood } \\
\text { F-statistic } \\
\text { Prob(F-statistic) }\end{array}$ & $\begin{array}{r}0.544705 \\
0.498515 \\
4.919775 \\
1670.089 \\
-227.7161 \\
11.79286 \\
0.000000\end{array}$ & $\begin{array}{l}\text { Mean depen } \\
\text { S.D. depend } \\
\text { Akaike info } \\
\text { Schwarz crit } \\
\text { Hannan-Qui } \\
\text { Durbin-Wats }\end{array}$ & $\begin{array}{l}\text { nt var } \\
\text { t var } \\
\text { erion } \\
\text { on } \\
\text { criter. } \\
\text { itat }\end{array}$ & $\begin{array}{l}5.568831 \\
6.947307 \\
6.122496 \\
6.366008 \\
6.219899 \\
0.993493\end{array}$ \\
\hline
\end{tabular}

Sumber: (Data Diolah, 2019)

Ho: Model REM yang dipilih (Prob > 0,005)

Pendekatan REM yang digunakan untuk uji regresi klasiknya

Karena model FEM yang lebih sesuai dengan data yang ada maka dibandingakan model FEM dengan model REM dengan menggunakan uji Hausman. Hasil dari uji Hausman pendekatan REM yang digunakan dalam untuk uji regresi kasiknya dalam kasus penelitian ini. 


\section{Uji normalitas}

Tabel 6. Hasil Uji Normalitas

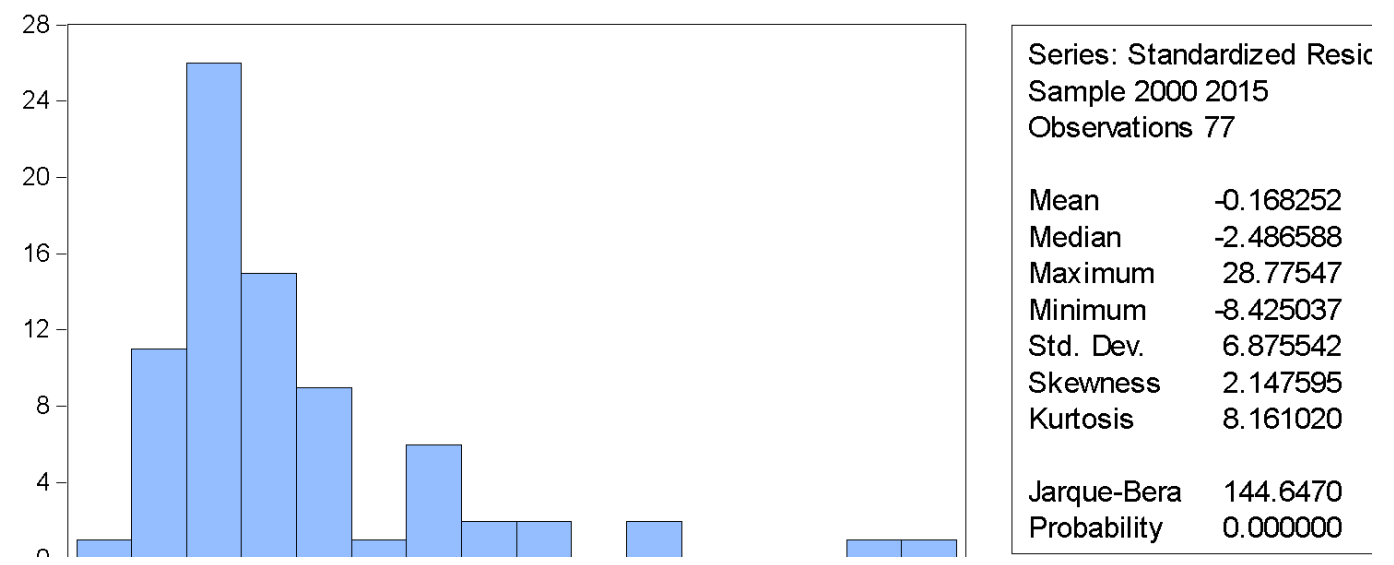

Sumber: (Data Diolah, 2019)

Nilai probabilitasnya $<0,05$ berarti data ini tidak terdistribusi normal. Data tidak terdistribusi tidak normal ini bisa disebabkan karena adanya data outlier. Untuk mengatasi data outlier ini akan digunakan transformasi logaritma untuk variabel dependen nya.

Tabel 7. Hasil Uji Normalitas Lanjutan

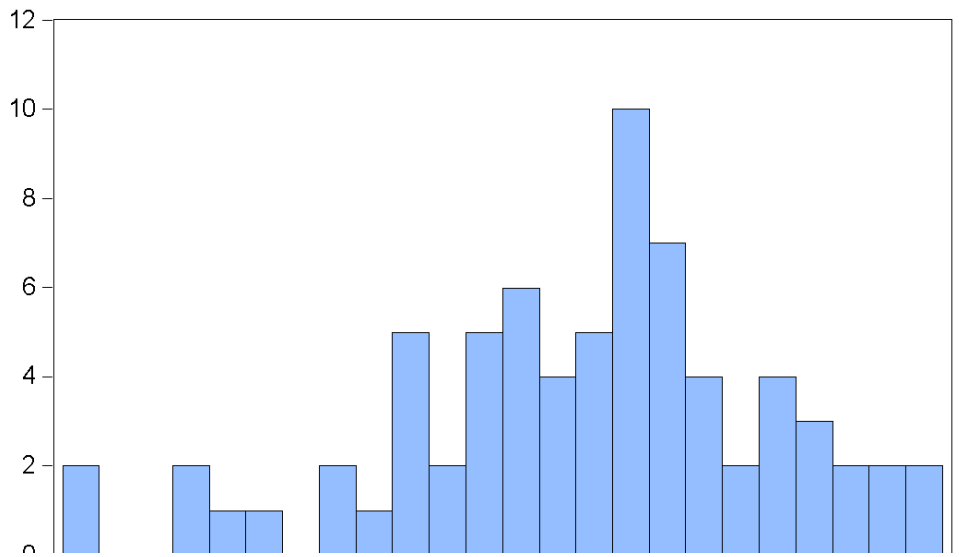

\begin{tabular}{|ll}
\hline \multicolumn{2}{|l}{ Series: Standardized Resic } \\
Sample 20002015 \\
Observations & 72 \\
& \\
Mean & 0.061610 \\
Median & 0.245729 \\
Maximum & 2.482390 \\
Minimum & -3.396750 \\
Std. Dev. & 1.285053 \\
Skewness & -0.578234 \\
Kurtosis & 3.277781 \\
& \\
Jarque-Bera & 4.243737 \\
Probability & 0.119808 \\
\hline
\end{tabular}

Sumber: (Data Diolah, 2019)

Sekarang data ini sudah terdistribusi normal karena nilai prob $(0,119)>0,05$. 


\section{Uji Multikolinearitas}

Akan mengujikan antara variabel independennya

Tabel 8. Hasil Uji Multikolin

\begin{tabular}{cccc} 
& X1 & X2 & X3 \\
\hline \hline X1 & 1.000000 & 0.409636 & 0.420544 \\
X2 & 0.409636 & 1.000000 & 0.800901 \\
X3 & 0.420544 & 0.800901 & 1.000000
\end{tabular}

Sumber: (Data Diolah, 2019)

Menurut (Ghozali, 2013) jika matriks korelasi tersebut tidak ada nilai > 0.90 maka tidak terjadi multi kolinearitas dalam model. Selanjutnya adalah uji heteroskedastisitas, untuk mengkorelasikan antara variabel $\mathrm{X} 1, \mathrm{X} 2$ dan X3 dengan nilai abs atau nilai residualnya.

\section{Uji Heteroskedastisitas}

Pada umum nya uji heteroskedastisitas disajikan dalam dua macam yaitu

1. Outout grafik

2. Output statistic

Tabel 9. Hasil Uji Heteroskedastisitas

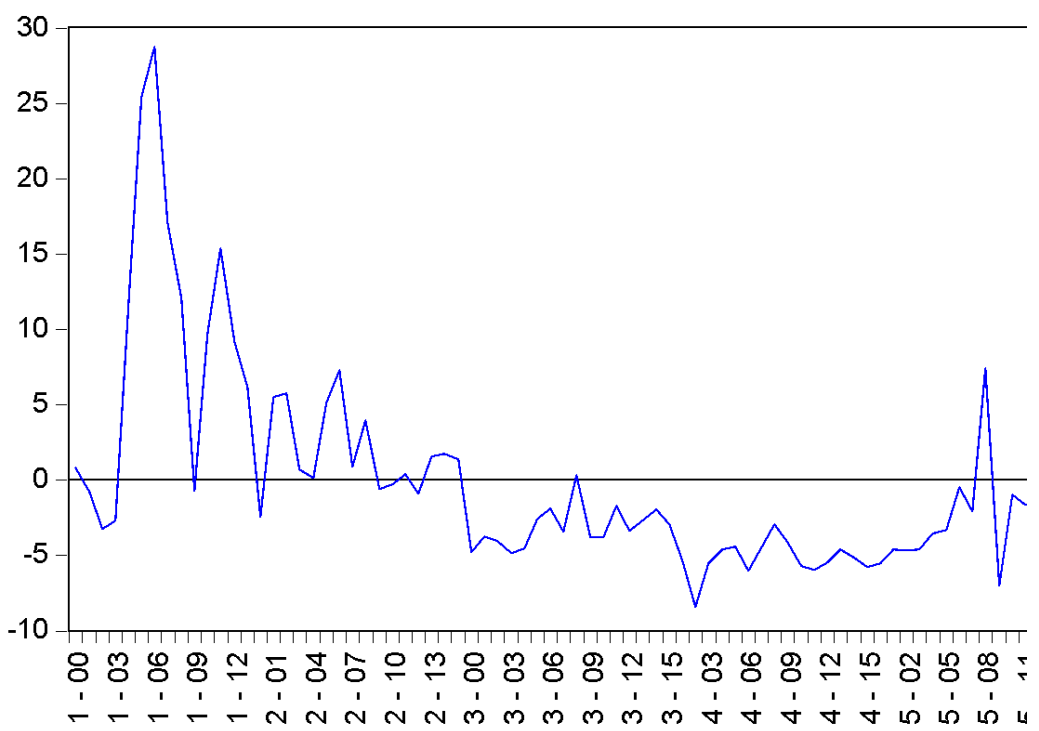

Sumber: (Data Diolah, 2019) 
Jika grafik tidak menunjukkan pola tertentu dapat diasumsikan bahwa tidak terdapat gejala heteroskedastisitas. Karena grafik cenderung sulit untuk dinilai maka perlu dilakukan uji statistik untuk mengetahui gejala heteroskedastisitas.

Tabel 10. Uji Statistik untuk mengetahui Gejala Heteroskedastisitas

\begin{tabular}{|c|c|c|c|c|}
\hline \multicolumn{5}{|c|}{$\begin{array}{l}\text { Dependent Variable: RESABS } \\
\text { Method: Panel Least Squares } \\
\text { Date: } 10 / 11 / 19 \text { Time: } 15: 00 \\
\text { Sample: } 20002015 \\
\text { Periods included: } 16 \\
\text { Cross-sections included: } 5 \\
\text { Total panel (unbalanced) observations: } 72 \\
\end{array}$} \\
\hline Variable & Coefficient & Std. Error & t-Statistic & Prob. \\
\hline C & 1.483965 & 0.163636 & 9.068694 & 0.0000 \\
\hline$\times 1$ & -0.066610 & 0.037774 & -1.763383 & 0.0823 \\
\hline$\times 2$ & $-3.19 E-06$ & $1.68 E-06$ & -1.903849 & 0.0612 \\
\hline$\times 3$ & $5.44 \mathrm{E}-06$ & $2.61 \mathrm{E}-05$ & 0.208356 & 0.8356 \\
\hline R-squared & 0.197866 & \multicolumn{2}{|c|}{ Mean dependent var } & 1.001880 \\
\hline Adjusted R-squared & 0.162477 & \multicolumn{2}{|c|}{ S.D. dependent var } & 0.798316 \\
\hline S.E. of regression & 0.730589 & \multicolumn{2}{|c|}{ Akaike info criterion } & 2.264022 \\
\hline Sum squared resid & 36.29573 & \multicolumn{2}{|c|}{ Schwarzcriterion } & 2.390504 \\
\hline Log likelihood & -77.50480 & \multirow{2}{*}{\multicolumn{2}{|c|}{$\begin{array}{l}\text { Hannan-Quinn criter. } \\
\text { Durbin-Wats on stat }\end{array}$}} & 2.314375 \\
\hline F-statistic & 5.591278 & & & 1.054035 \\
\hline Prob(F-statistic) & 0.001733 & & \\
\hline
\end{tabular}

Sumber: (data diolah, 2019)

Dari hasil uji heteroskedastisitas didapat bahwa tidak ada gejala heteroskedastisitas karena nilai prob semuanya variabel independennya $>0,05$. Sehingga tidak ada gejala asumsi klasik dalam data ini maka layak untuk dilakukan uji regresi karena tidak ada gejala heteroskedastisitas. Dari hasil REM secara parsial X1,X2 dan X3 tidak memiliki pengaruh dan dari nilai prob (F statistik) secara simultan $\mathrm{X} 1, \mathrm{X} 2$ dan $\mathrm{X} 3$ juga tidak mempunyai pengaruh.

\section{ANALISIS}

Hasil dari beberapa tahapan regersi data panel yang sudah dilakukan, data dalam penelitian ini lebih baik dilakukan dengan pendekatan model random effect. REM ini berbeda dengan uji CEM dan FEM, terutama modrl ini tidak menggunakan prinsip ordinary least square melainkan mengunakan prinsip maksimum likehood atau general least square. Dalam eviews akan dihasilkan dua output dalam REM yaitu weighted dan unweighted.

Model REM ini dapat mengatasi masalah ketidakpastian model yanmg digunakan dengan menggunakan variabel residual. Pada REM, residual mungkin saling berhubungan antar waktu dan antar individu atau cross section. Oleh karena itu model ini menggunakan asumsi bahwa ada perbedaan intersep untuk setiap individu dan intersep tersebut adalah variabel random. Sehingga dalam model REM ada dua komponen residual, yaitu residual secara menyeluruh dimana residual tersebut merupakan kombinasi dari cross section dan time series. Sedangkan residual yang kedua adalah residual secara individual yang 
merupakan karakteristik random dari observasi unit ke-I dan tetap sepanjang waktu. Persamaan regresi data panel REM adalah sebagai berikut:

$$
y_{i t}=\alpha+\boldsymbol{\beta}^{\prime} \boldsymbol{X}_{i t}+u_{i}+\varepsilon_{i t}
$$

Keterangan,

Untuk $\mathrm{I}=1.2 \ldots ., \mathrm{N}$ dan $\mathrm{t}=1,2, \ldots, \mathrm{T}$

Dimana $\mathrm{N}=$ jumlah individu atau cross section

$\mathrm{T}=$ jumlah periode waktunya

Eit $=$ adalah residual secara menyeluruh diman residual tersebut merupakan kombinasi dari cross section dan time series.

$\mathrm{Ui}=$ adalah residual secara individual yang merupakan karakteristik random dari observasi unit ke-I dan tetap sepanjang waktu.

Pendekatan yang dipakai dalam REM mengasumsikan setiap negara mempunyai perbedaan intersep, dimana intersep tersebut adalah variabel random atau stokastik. Dan model REM ini sangat berguna karena negara yang dipilih adalah diambil sebagai sampel yang dipilih secara random sebagai wakil populasi dari IDB. REM juga memperhitungkan bahwa error mungkin berkorelasi sepanjang cross section dan time series.

Hasil multikolinearitas didapat bahwa tidak terdapat hubungan korelasi antar variabel independen artinya terhindar dari unsur trend dari data time series yang biasanya data bergerak naik dan turun secara bersamaan.

Sehingga didapat persamaan regresi data panelnya sebagai berikut.

$\mathrm{Y}=5.485+0.179 \mathrm{X} 1-4.08 \mathrm{E}-06 \mathrm{X} 2$ - 4.21E-05X3

Dimana,

$\mathrm{Y}=$ inflasi

$\mathrm{X} 1=\mathrm{GDP}$

$\mathrm{X} 2=$ Ekspor

$\mathrm{X} 3$ = Investasi

Berdasarkan persamaan regresi tersebut dapat dianalisis pengaruh masing-masing variabel independen terhadap variabel dependen, yaitu

Konstanta a sebesar 5.485 menyatakan bahwa jika nilai dari GDP, ekspor dan investasi konstan (0) maka nilai variabel inflasi adalah sebesar 5.485.

Nilai koefisien regresi X1 memiliki hubungan positif 0.179 untuk variabel GDP, artinya setiap perubahan rasio $1 \%$ rasio GDP maka inflasi akan mengalami kenaikan sebesar 0.179 satuan, dalam hal ini faktor lain dianggap tetap.

Nilai koefisien regresi X2 memiliki hubungan negatif - 4.08E-06 untuk variabel ekspor yang artinya setiap kenaikan $1 \%$ rasio ekspor maka inflasi akan mengalami penurunan sebesar 4.08E-06 satuan, dalam hal ini faktor lain dianggap tetap.

Nilai koefisien regresi X3 memiliki hubungan negatif - 4.21E-05 untuk variabel investasi yang artinya setiap kenaikan $1 \%$ rasio investasi maka inflasi akan mengalami penurunan sebesar 4.21E-05 satuan, dalam hal ini faktor lain dianggap tetap. 


\section{KESIMPULAN}

Dari hasil uji regresi data panel dilihat bahwa ketiga variabel independen berpengaruh terhadap variabel dependen tetapi tidak signifikan. Dimana hubungan antara DGP dan inflasi positif, artinya bila GDP naik maka inflasi juga naik. Sedangkan hubungan antara ekspor dan investasi terhadap inflasi adalah negatif. Artinya bila ekspor naik maka inflasi turun dan jika investasi naik maka inflasi akan turun. Sehingga secara umum kebijakan pemerintah dari lima negara anggota IDB tersebut harus lebih berpihak kepada menaikkan tingkat ekspor dan investasi di dalam negeri baik investasi asing atau investasi domestik untuk membantu menurunkan tingkat inflasi dalam negeri.

Perlu adanya penelitian yang lebih mendalam per negara dikupas secara mendalam. Karena maslah inflasi disatu negara bisa sangat berbeda pengaruhnya dengan di negara lainnya. Walaupun secara umum inflasi sangat merusak perekonomian.

\section{DAFTAR PUSTAKA}

Agustina dan Reny, (2014). "Pengaruh Ekspor, Impor, Nilai Tukar Rupiah dan Tingkat Inflasi terhadap Cadangan Devisa Indonesia”, Jurnal Wira Ekonomi Mikroskil, Vol 4 No. 2 hal. 69.

Agustina Hilda.(2015). Negara Guinea https://hildaagustina.blogspot.com/2015/06/negaraguinea.

Aji Tony Seno dan Musdholifah. (2007). Analisis Pengaruh Variabel Makroekonomi terhadap Inflasi di Indonesia (Inflasi, Defisit Anggran Pemerintah, Produksi Minyak dan Gas Bumi, jumlah uang yang beredar, tingkat suku bunga, nilai tukar rupiah terhadap dolar Amerika.

Al Quran. Kitab Suci agama Islam.

Alotaibi, A. R. and Mishra, A. V. (2014). Determinants of International Financial Integration of GCC Markets Emerging Markets and the Global Economy, Elsevier, http://dx.doi.org/10.1016/B978-0-12-411549-1.00031-4.

Aryawan I Made Gitra (2009) Pengaruh Jumlah Uang Beredar dan PDB Terhadap Laju Inflasi di Indonesia Tahun 2000-2007 (Inflasi, Jumlah Uang Beredar, PDB).

Asamoah, M. E., Adjasi, C.K.D., and Alhassan, A.L. (2016). Macroeconomic Uncertainty, Foreign Direct Investment And Institutional Quality: Evidence from Sub-Saharan Africa. Economic Systems, 40(4), 612-621.

Baltas, N.C. (2013). The Greek Financial Crisis and the Outlook of the Greek Economy. Journal of Economic Asymmetries, 10(1), 32-37. https://doi.org/10.1016/j.jeca.2013.09.002.

Benny, Jimmy. (2013). "Ekspor Dan Impor Pengaruhnya Terhadap Posisi Cadangan Devisa Di Indonesia”. Jurnal Ekonomi, Manajemen, Bisnis dan Akuntansi, 1 (4): 1406-15.

Binici, M., Cheung, Y.-W., and Lai, K.S. (2012). Trade Openness, Market Competition, And Inflation: $\mathrm{S}$ ome sectoral evidence from OECD countries. International Journal of Finance Economics, 17(4), 321-336.

Boediono, (1988). Ekonomi Moneter, Edisi 3, BPFE, Yogyakarta.

Busse, M., and Hefeker, C. (2007). Political Risk, Institutions And Foreign Direct Investment. European Journal of Political Economy, 23(2), 397-415. https://doi.org/10.1016/j.ejpoleco.2006.02.003. 
Committee for Economic and Commercial Coorporation of The Organization of Islamic Coorperation (COMCEC), (2018). COMCEC Trade Outlook. Ankara: COMCEC Coordination Office.

Committee for Economic and Commercial Coorporation of The Organization of Islamic Coorperation (COMCEC), (2019). Annual Report On Trade Among The OIC Member State. Ankara: The Islamic Centre for Development of Trade.

Dumairy. (1999). Perekonomian Indonesia. Jakarta: Penerbit Erlangga.

Fahmi, I. (2014). Manajemen keuangan perusahaan dan pasar modal. Jakarta: Mitra Wacana Media.

Gujarati, D. N., and Porter, D. C. (2009). Basic Econometrics (5th ed.). New York: McGraw-Hill/Irwin.

Herrera-Echeverri, H., Haar, J., and Estevez- Breton, J. B. (2013). Foreign Direct Investment, Institutional Quality, Economics Freedom and Entrepreneurship in Emerging Markets. Journal of Business Research, 1921-1932. http://doi.org/10.1016/j.jbusres.2013-11-020.

https://anisullailahputri.wordpress.com/2015/06/17/pengaruh-inflasi-dan-pendapatan-

terhadap-impor/. https://doi.org/10.1016/j.ecosys.2016.02.010

https://isdbdata.github.io/monograph2017.html.

https://www.diedit.com/negara-terkaya-di-dunia/.

https://www.gurugeografi.id/2017/05/perbedaan-gnp-gdp-dan-gni.html.

Huda Nurul et al 2012 Islamic public Finance: theoretical and historical approaches (Jakarta: Kencana)

Ikasari Hertiana. (2015). Determinan Inflasi (Pendekatan Klasik) Laju inflasi, Uang Primer, PDB Riil Journal of Economic Studies Emerald Insight 2015.

Kang. J.W. and Dagli. S. (2018). Internasional Trade and Exchange Rates. Journal of Applied Economics, Vol. 21, No. 1, 84-105, https://doi.org/10.1080/15140326.2018.1526878.

Kaufmann, D., Kraay, A., and Mastruzzi, M. (2010). The Worldwide Governance Indicators Methodology and Analytical Issue (No. 5430).

Kurniawan Dedi (2008). Regresi Linier $R$ Development Core Team (2008). R: A language and environment for statistical computing. $R$ Foundation for Statistical Computing, Vienna, Austria. ISBN 3-900051-07-0, URL http://www.R-project.org.

Listiani Nurlia. (2006). Faktor-Faktor Determinan yang Mempengaruhi Tingkat Inflasi di Indonesia periode 1970-2004 (IHK, GDP riil, nilai tukar riil, pertumbuhan upah riil, pertumbuhan JUB, pertumbuhan harga impor).

Majid, M Nazori. (2003) Pemikiran Ekonomi Islam Abu Yusuf Relevansinya dengan Ekonomi Kekinian. Jakarta; Pusat Studi Ekonomi Islam (PSEI).

Majoka, M. I., Sahibzada, H. E., and Khan, M.S. (2012). Resources of The Muslim World: A Reflection on the Muslim World's Resources, Their Development and Utilization. Journal of Islamic Thought and Civilization (JITC), 2(1).

Mendonca, H. F. D. and Nascimento, N.C. (2018). Monetery Policy Eficiency And Macroeconomic Stability: Do Financial Openness And Economic Globalization Matter? North American Journal of Economics and Finance, 1-20. https://doi.org/10.1016/j.najef.2018.10.018.

Miller, T., Kim, A. B., Roberts, J. M. and Tyrrell, P. (2019). Highlight of The 2019 Index of Economic Freedom. Washington, DC: The Heritage Foundation. 
Mishkin, F. s. (2008). Ekonomi Uang, Perbankan, dan Pasar Keuangan Edisi 8. Jakarta: Salemba Empat.

Nanga Muana. (2005). Makroekonomi Teori Masalah dan Kebijakan Ed kedua (Jakarta: PT Raja Grafika Persada).

Nurfadhilla, L. (2019). Pengaruh Sistem Pembayaran Non-Tunai Pada Era Digital Terhadap Tingkat Inflasi Di Indonesia. Jurnal Ekonomi dan Bisnis.

Setyawati, Irma. (2017) Does Financial Performance Of Islamic Banking Is Better? European Research Studies Journal.

Sonia, Agnes dan Nyoman Djinar Setiawina. (2016). "Pengaruh Kurs, Jub Dan Tingkat Inflasi Terhadap Ekspor, Impor Dan Cadangan Devisa Indonesia" E- Jurnal Ekonomi Pembangunan. Universitas Udayana, Vol. 5, No. 10. : 1077- 1102.

Todaro, P. (2002). Pembangunan Ekonomi Dunia ke Tiga,Edisi 7. Erlangga. Jakarta.

Tulus, T. (2008). Pembangunan Ekonomi dan Utang Luar Negeri. Jakarta: Rajawali. 